\title{
A rare case of a bifurcated uvula in a 20-year-old
}

\author{
Michelle Hernandez, ${ }^{1}$ Andrew George, ${ }^{2}$ Latha Ganti (i) 1,3
}

${ }^{1}$ University of Central Florida College of Medicine, Orlando, Florida, USA

${ }^{2}$ Brown University, Providence, Rhode Island, USA

${ }^{3}$ Envision Physician Services, Plantation, Florida, USA

\section{Correspondence to} Professor Latha Ganti; lathagantimd@gmail.com

Accepted 3 March 2021

\section{DESCRIPTION}

A 20-year-old man presented to the emergency department with a sore throat and general malaise for 2 days. On evaluation, an incidental bifurcated uvula was noted without any acute oropharyngeal abnormalities (figure 1). He reported the bifurcated uvula was likely congenital as his parents were informed of it shortly after his birth.

The patient denied any relevant medical history or any other known abnormalities since birth. A rapid group A streptococcus test was performed in the emergency department, which was negative. The patient was discharged with return precautions and primary care follow-up.

A bifid uvula or bifurcated uvula is a uvula with a visible cleft. While prevalence rates ranging from $0.18 \%$ to $10.3 \%$ have been documented throughout existing literature, with higher rates in South and East Asians and lower rates in Africans, the condition is often diagnosed and corrected in infancy and rarely found in adults. ${ }^{1-3}$ Though typically a benign finding with no consequence on airway integrity, a cleft uvula, along with nasal intonation, can indicate a submucosal cleft palate. ${ }^{4}$ Moreover, it has been shown to be sometimes associated with recurrent middle ear infections and nasal regurgitation during swallowing. ${ }^{5}$ However, our patient, although his voice may have been slightly nasal, did not have a notch in the back of the hard palate or translucency of the tissue along the middle of the soft palate, features that would suggest a submucosal cleft palate.

In rare circumstances, a bifid uvula can be associated with more serious complications. Patients with Loeys-Dietz syndrome (LDS), for which a bifid uvula is a common symptom, are at higher risk for

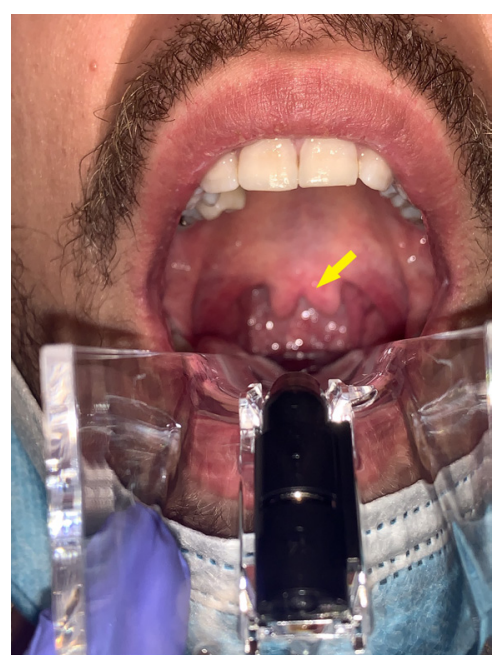

Figure 1 Clinical photograph using a lighted speculum demonstrating a bifurcated uvula (arrow). aggressive arterial aneurysms, allergic and inflammatory disease, gastrointestinal inflammation and pregnancy-related complications for women with LDS. $^{6}$ Our patient did not have any other typical LDS physical exam findings such as widely spaced eyes, strabismus or pectus excavatum. He denied history of aneurysms, joint laxity or the propensity to bruise easily.

Because the bifid uvula both is often benign and can also be associated with complications (most often speech abnormality due to nasal intonation and nasal regurgitation when swallowing), finding a bifid uvula in an adult patient is a rarity. Nevertheless, the possibility should not be overlooked in patients suspected for LDS or presenting with other associated signs and symptoms.

Acknowledgements This research was supported (in whole or in part) by HCA Healthcare and/or an HCA Healthcare-affiliated entity. The views expressed in this publication represent those of the author(s) and do not necessarily represent the official views of HCA Healthcare or any of its affiliated entities.

Contributors MH saw the patient, documented patient's course and took images. AG wrote description for accompanying images and edited submission. LG—submitting and corresponding author-edited description and compiled images, saw patient and obtained patient consent.

Funding The authors have not declared a specific grant for this research from any funding agency in the public, commercial or not-for-profit sectors.

Competing interests None declared.

Patient consent for publication Obtained.

Provenance and peer review Not commissioned; externally peer-reviewed.

\section{Patient's perspective}

Yeah, everyone always thinks it (my uvula) is so weird.

\section{Learning points}

A bifid uvula, while a rare but often benign sign, can sometimes be indicative of a submucosal cleft palate and is associated with recurrent middle ear infections and nasal regurgitation on swallowing.

- Finding a bifid uvula in an adult patient is an extremely rare occurrence.

- A bifid uvula, due to the potential association with Loeys-Dietz syndrome and the complications thereof, should not be dismissed when found despite its often benign tendency. 


\section{Images in...}

\section{ORCID iD}

Latha Ganti http://orcid.org/0000-0001-7717-3864

\section{REFERENCES}

1 Feka $\mathrm{P}$, Banon J, Leuchter I, et al. Prevalence of bifid uvula in primary school children. Int J Pediatr Otorhinolaryngol 2019;116:88-91.

2 Sales SAG, Santos ML, Machado RA, et al. Incidence of bifid uvula and its relationship to submucous cleft palate and a family history of oral cleft in the Brazilian population. Braz J Otorhinolaryngol 2018;84:687-90.
3 Alroyayamina S, McKnight M. Keep an eye out for the bifid Uvula: a case report. Dent Update 2015:42:247-9.

4 Shprintzen RJ, Schwartz RH, Daniller A, et al. Morphologic significance of bifid uvula. Pediatrics 1985;75:553-61.

5 Samanta S, Samanta S. Bifid uvula: Anesthetist don't take it lightly! Saudi J Anaesth 2013;7:482-4.

6 Loeys BL, Dietz HC. Loeys-Dietz Syndrome. In: Adam MP, Ardinger HH, Pagon RA, eds. GeneReviews. Seattle: University of Washington, 1993. http://www.ncbinlm.nih.gov/ books/NBK1133/

Copyright 2021 BMJ Publishing Group. All rights reserved. For permission to reuse any of this content visit

https://www.bmj.com/company/products-services/rights-and-licensing/permissions/

BMJ Case Report Fellows may re-use this article for personal use and teaching without any further permission.

Become a Fellow of BMJ Case Reports today and you can:

- Submit as many cases as you like

- Enjoy fast sympathetic peer review and rapid publication of accepted articles

- Access all the published articles

- Re-use any of the published material for personal use and teaching without further permission

\section{Customer Service}

If you have any further queries about your subscription, please contact our customer services team on +44 (0) 2071111105 or via email at support@bmj.com.

Visit casereports.bmj.com for more articles like this and to become a Fellow 